\title{
Feigned HIV infection/AIDS: malingering and Munchausen's syndrome
}

\author{
D R Churchill, K M De Cock, R F Miller
}

Department of Medicine, The Middlesex Hospital, Mortimer Street, London W1N 8AA

D R Churchill

$\mathrm{K} M$ De Cock

R F Miller

Correspondence to: Dr D R Churchill, Winston Churchill Wing, St Mary's Hospital, Praed Street, London W2 $1 \mathrm{NY}$, UK

Accepted for publication 4 May 1994

\begin{abstract}
Feigned HIV infection or acquired immunodeficiency syndrome (AIDS), in which people mimic infection with or disease due to HIV, accounted for $1.7 \%$ of admissions to our specialist HIV unit in Central London over a 5 year period. Of 12 patients with feigned HIVIAIDS, 11 were HIV antibody-negative, and one refused testing. Presenting histories were sometimes grandiose, unusually tragic, or unlikely in relation to the patients' healthy appearance, and often included admissions to other specialist HIV units. Substance abuse was suspected in over half of the patients described, a higher frequency than that observed in our HIVinfected patient population. The possibility of feigned HIVIAIDS should be remembered in persons with selfreported HIV infection. Recognition of this condition is important to avoid costly and potentially dangerous investigation and therapy.
\end{abstract}

(Genitourin Med 1994;70:314-316)

\section{Case history}

A 28 year old man was admitted to the HIV unit with a history of cough, fever and breathlessness. He claimed to have had a positive test for HIV antibody at a hospital in the North of England 3 years previously, and thought he had contracted the infection through homosexual contact. He described numerous admissions to at least three different hospitals in the preceding three years for treatment of gastrointestinal bleeding, multiple abscesses, chest infections and trauma, and claimed to have been treated for six months with zidovudine for symptomatic HIV infection. He also described approximately 20 previous suicide attempts, and admitted to drinking 60 or more units of alcohol per week. Examination was normal. Chest radiograph, arterial blood gases and exercise oximetry were also normal, but a neutrophil leucocytosis was noted and an induced sputum sample revealed a heavy growth of Streptococcus pneumoniae. He was treated uneventfully with amoxycillin.

With his consent, a confirmatory HIV antibody test was performed. The result was negative, but he left the ward before receiving it. Hospitals that he had previously attended were contacted, revealing a long history of feigned HIV disease. A review of case notes revealed eleven other cases of confirmed or suspected feigned HIV infection and AIDS presenting to the unit over the preceding 5 years (table).

\section{Discussion}

Asher's original description of Munchausen's syndrome, ${ }^{3}$ in which patients gain admission to many different hospitals with grandiose and

Table Data of cases feigning HIVIAIDS

\begin{tabular}{|c|c|c|c|c|c|c|c|c|c|c|c|}
\hline No & Year & $\begin{array}{l}\text { Age } \\
\text { (years) }\end{array}$ & Sex & $\begin{array}{l}\text { Alleged } \\
\text { Risk Group }\end{array}$ & $\begin{array}{l}\text { Alleged } \\
\text { HIV History }\end{array}$ & $\begin{array}{l}\text { Presenting } \\
\text { Complaint }\end{array}$ & $\begin{array}{l}\text { Results of } \\
\text { Investigation }\end{array}$ & $\begin{array}{l}\text { HIV } \\
\text { Antibody }\end{array}$ & $\begin{array}{l}C D 4 \\
10^{6} / l\end{array}$ & $\begin{array}{l}\text { Stay } \\
\text { (days) }\end{array}$ & Outcome \\
\hline 1 & 1988 & 21 & $\mathbf{F}$ & Raped & $\begin{array}{l}\text { PCPx4, CMV, } \\
\text { PID }\end{array}$ & $\begin{array}{l}\text { Chest pain } \\
\text { breathless }\end{array}$ & Normal & Negative & N/A & 11 & Discharged \\
\hline 2 & 1990 & 33 & $\mathbf{M}$ & IVDU & $\begin{array}{l}\text { HIV +, gastrointestinal } \\
\text { bleeding }\end{array}$ & GI Bleed & Normal & Negative & N/A & 10 & Discharged \\
\hline 3 & 1990 & 36 & $\mathbf{M}$ & IVDU & $\begin{array}{l}\text { HIV }+3 \text { months } \\
\text { Tested in prison }\end{array}$ & $\begin{array}{l}\text { Cough } \\
\text { fever }\end{array}$ & Bronchitis & Negative & N/A & 7 & Discharged \\
\hline 4 & 1990 & 33 & $\mathbf{M}$ & Homosexual & $\begin{array}{l}\text { HIV }+2 \text { months } \\
\text { Tested in prison }\end{array}$ & $\begin{array}{l}\text { Breathless, } \\
\text { cough }\end{array}$ & Normal & Negative & N/A & 1 & Discharged \\
\hline $\begin{array}{l}5 \\
6 \\
7\end{array}$ & $\begin{array}{l}1990 \\
1990 \\
1991\end{array}$ & $\begin{array}{l}27 \\
25 \\
25\end{array}$ & $\begin{array}{l}M \\
M \\
F\end{array}$ & $\begin{array}{l}\text { Homosexual } \\
\text { IVDU } \\
\text { IVDU } \\
\text { Raped }\end{array}$ & $\begin{array}{l}\text { HIV }+7 \text { months } \\
\text { HIV }+12 \text { months } \\
\text { HIV p } 24 \text { ag positive } \\
\text { HIV antibody negative }\end{array}$ & $\begin{array}{l}\text { Seizures } \\
\text { Cellulitis } \\
\text { Abdominal } \\
\text { pain }\end{array}$ & $\begin{array}{l}\text { Normal } \\
\text { Cellulitis } \\
\text { Nil found }\end{array}$ & $\begin{array}{l}\text { Negative } \\
\text { Negative } \\
\text { Negative } \\
\text { (p24 neg) }\end{array}$ & $\begin{array}{l}\text { N/A } \\
\text { N/A } \\
\text { N/A }\end{array}$ & $\begin{array}{l}10 \\
23 \\
12\end{array}$ & $\begin{array}{l}\text { Left ward } \\
\text { Discharged } \\
\text { HIV positive } 1993\end{array}$ \\
\hline 8 & 1992 & 29 & $\mathbf{M}$ & $\begin{array}{l}\text { Homosexual } \\
\text { IVDU }\end{array}$ & $\mathrm{HIV}+5$ years & Weak legs & Normal & Negative & 890 & 7 & $\begin{array}{l}\text { Declined further } \\
\text { follow up }\end{array}$ \\
\hline 9 & 1993 & 24 & $\mathbf{M}$ & Haemophiliac & $\begin{array}{l}\text { PCPx4, oesophageal } \\
\text { candidiasis }\end{array}$ & $\begin{array}{l}\text { Suicidal } \\
\text { partner died }\end{array}$ & Normal & Refused & 480 & 2 & Discharged \\
\hline 10 & 1993 & 32 & $\mathbf{M}$ & IVDU & $\begin{array}{l}\text { HIV }+5 \text { months } \\
\text { Tested in prison }\end{array}$ & $\begin{array}{l}\text { Methadone } \\
\text { overdose }\end{array}$ & $\begin{array}{l}\text { Overdose } \\
\text { Bronchitis }\end{array}$ & Negative & 820 & 4 & Discharged \\
\hline 11 & 1993 & 16 & $\mathbf{M}$ & Homosexual & $\begin{array}{l}\text { Pneumonia HIV + ve } \\
\text { Partner died of AIDS }\end{array}$ & $\begin{array}{l}\text { Cough } \\
\text { fever }\end{array}$ & Normal & Negative & 1390 & 5 & Discharged \\
\hline 12 & 1993 & 28 & $\mathbf{M}$ & Homosexual & HIV + 3 years & $\begin{array}{l}\text { Cough } \\
\text { fever }\end{array}$ & Bronchitis & Negative & 1010 & 5 & Left ward \\
\hline
\end{tabular}

Details of patients with feigned HIV infection. (IVDU = Intravenous drug user, PID = pelvic inflammatory disease, PCP = pneumocystis carinii pneumonia, CMV $=$ cytomegalovirus retinitis). Patient 1 previously reported. ${ }^{12}$ Normal CD4 count 350-2200. 
dramatic histories of invented illnesses, was written 30 years before AIDS was recognised. Factitious AIDS was first described in 1986, and from reviewing the literature we identified 41 cases of feigned and factitious AIDS/HIV infection. ${ }^{12-22}$

Previous authors have drawn a distinction between malingering, in which false symptoms and signs are produced in order to obtain some advantage, and factitious disorders (including Munchausen's syndrome), in which there is no discernible benefit from the feigned illness. ${ }^{23}$ Patients feigning HIV infection are particularly difficult to categorise in this way, as possible benefits of the fabricated illness can usually be identified in all patients. ${ }^{21}$ We have thus considered together all patients falsely claiming to be HIV antibody positive. The possible motives that we identified in our patients for feigning HIV infection included access to controlled drugs, to HIV/AIDS support services (such as housing, benefits), and to sympathetic staff. In two cases it was clear that admission to hospital enabled the patient to avoid court hearings.

Because patients may have multiple admissions to different hospitals, under different names, and because of controversy about diagnostic criteria, ${ }^{9123}$ it is difficult to estimate the true prevalence of Munchausen's syndrome, factitious disorders, and malingering in which the presenting problem is unrelated to HIV infection. Stern reported only 10 cases of Munchausen's syndrome presenting to Massachusetts General Hospital over a 10 year period. ${ }^{24}$ We found 12 cases of feigned HIV infection (of whom Munchausen's syndrome could clearly be diagnosed in at least four), presenting to our unit in 5 years, during which time a total of 714 patients were admitted to the inpatient unit, giving a prevalence of $1.7 \%$. This suggests that the problem is much more common than previously recognised.

Four of the twelve patients had genuine medical problems which required treatment, although they were HIV antibody-negative. All patients claimed to be in groups at high risk for HIV infection. Previous authors ${ }^{18}$ have reported a high prevalence of drug use amongst patients feigning HIV infection. Six of our patients had a history of injecting drug use, and two further patients were suspected drug users; of all patients admitted to the unit during the period of the study whose risk factor for HIV infection could be identified, only $7 \cdot 2 \%$ were injecting drug users. Three patients (two of whom were injecting drug users) claimed to have been tested for HIV antibody whilst in prison. Levine ${ }^{8}$ and Cooke $^{25}$ described patients who were genuinely HIV antibody-positive but feigned AIDS; we encountered no such patients in our study. One patient (Patient 7) presented originally claiming to have been found to be HIV antibody-negative but repeatedly positive for HIV p24 antigen at another hospital. She claimed to have forgotten the false name she had used at the previous hospital, making it difficult to corroborate her story. She was found to be negative for both HIV antibody and p24 antigen, and her records at the previous hospital were eventually traced, confirming that she had never tested positive for HIV antigen or antibody. She continued to inject drugs. Two years later she presented requesting termination of pregnancy, and was found to be HIV antibody-positive.

In some patients with feigned HIV infection the diagnosis was suggested by a discrepancy between the patients' history and appearance; two patients with factitious AIDS described 5 prior major opportunistic infections each, but both appeared remarkably healthy and well-nourished. It is important to remember, however, that occasionally patients with factitious AIDS look very like patients with late-stage HIV infection. ${ }^{21}$ In the group as a whole, patients' histories seemed unusually dramatic or tragic; for example two patients claimed that their sexual partners had recently died of AIDS, and the two women in our series both claimed to have seroconverted for HIV after having been raped. We can only speculate whether these events were made up to attract the sympathy of staff, or did in fact occur (and may even have helped to precipitate feigned illness behaviour).

Patients with feigned HIV infection may present to hospitals where experience with HIV disease is limited, and patients with factitious disorders commonly use health care facilities outside of regular hours when the least experienced staff are on duty. ${ }^{25}$ It is our current policy to ask for consent for confirmation of HIV infection in new patients reporting that they are HIV-infected, and to stage infection by performing a CD $4+$ lymphocyte count. The latter may be useful for identifying discrepancies between a prior medical history and the clinical observations, as in case 9 (table). It is also important to attempt to confirm previous histories as soon as possible, by contacting the hospitals the patient has previously attended.

Of our twelve patients, two discharged themselves before receiving the result of their HIV antibody test, eight were informed of the result and discharged, one was not tested for HIV antibody until followed up after his admission to hospital, and one was not informed of the result. We are aware that at least four of the patients have continued to feign HIV infection after discharge from our unit. Others have suggested that a centralised register might aid earlier detection of patients with factitious disorders ${ }^{10}$; this would probably not contribute to earlier recognition of cases, however, and would compromise confidentiality. ${ }^{26}$ Psychiatric treatment of patients with factitious disorders is rarely successful, ${ }^{25}$ and the main aim of identifying patients with feigned HIV infection remains the avoidance of potentially dangerous and costly ${ }^{26}$ investigation and treatment.

We thank Jane Healing for secretarial assistance, and Gary Davis for help with data about admission rates to our wards. 
1 Kavalier FC. Munchausen AIDS. Lancet 1989;i:852 Joseph PL, Potter M. Munchausen AIDS in a bomb hoaxer. Med Sci Law 1991;31:259-60.

3 Asher R. Munchausen's syndrome. Lancet 1951;1:339-41.

4 Miller R, Weiden P, Sacks M, Wozniak J. Two cases of factitious acquired immune deficiency syndrome. $A m \mathcal{F}$ Psychiatry 1986;143:1483.

5 Baer JW. Case report: Munchausen's/AIDS. Gen Hosp Psychiatry 1987;9:75-6.

6 Robinson EN, Latham RH. A factitious case of acquired immunodeficiency syndrome. Sex Transm Dis 1987;14: 54-7.

7 Zumwault RE, McFeeley PJ, Maio J. Fraudulent AIDS. fAMA 1987;257:3231.

8 Levine SS, Helm ML. An AIDS diagnosis used as a focus of malingering. West $\mathcal{f}$ Med 1988;148:337-8.

9 Evans GA, Gill MJ, Gerhart S. Factitious AIDS. $N$ Engl f Med 1988;319:1605-6.

10 McDonald J, Wafer K. Munchausen Syndrome masquerading as AIDS-induced depression. Br $\mathcal{F}$ Psychiatry 1989;154:420-1

11 Silva IA, Leong GB, Weinstock R, Ready DJ. Factitious AIDS in a psychiatric inpatient. Can $\mathcal{F}$ Psychiatry 1989; $34: 320-2$.

12 Nickoloff SE, Neppe VM, Ries RK. Factitious AIDS. Psychosomatics. 1989;30:342-5.

13 Bialer PA, Wallack JJ. Mixed factitious disorder presenting as AIDS. Hosp Commun Psychiatry. 1990;41:552-3.

14 Cooke MW, Grace RH. The modern Munchausen syndrome. $\mathcal{F} R$ Soc Med 1990;83:272-3.
15 Frumkin LR, Victoroff JI. Chronic factitious disorder with symptoms of AIDS. Am $\mathcal{f}$ Med 1990;88:694-6.

16 Gockel KA, Vogelman B, Handy W, Graziano FM. Factious AIDS: a case presentation and review of the literature. Wis Med $\Im$ 1990;89:633-4.

17 Parmar M, Boag F, Jayasuriya P, Catalan J. Feigned HIV disease. Int $\mathcal{F} S T D$ AIDS 1990;1:447.

18 Murphy $M$, Mulcahy F. Feigned HIV disease. Int $\mathcal{f}$ STD AIDS 1991;2:215.

19 Sno HN, Storosum JG, Wortel CH. Psychogenic "HIV infection". Int $\mathcal{F}$ Psychiatry Med 1991;21:93-8.

20 Cottan SN, Cuthbert AC, Parapia LA. Munchausen AIDS and haemophilia Eur f Haematol 1991;46:125.

21 Zuger A, O'Dowd MA. The Baron has AIDS: a case of factitious human immunodeficiency virus infection and review. Clin Infect Dis 1992;14:211-6.

22 Taylor CB, George $H$, Newell ME, Nayagam AT, Collins M, Farrington A. Feigned HIV disease. Medical Society for the Study of Venereal Diseases, Spring Meeting, Dublin for the Study of Venereal Dised

23 Chiarello RI. Malingering doubt about factitious AIDS. $N$ Engl f Med 1989;320:1423.

24 Stern TA. Munchausen's syndrome revisited. Psychosomatics.1980;21:329-36.

25 Jacoby GA, Stern TA. A 39-year old man with gas in the soft tissues of the left forearm. $N$ Engl $f \mathrm{Med}$ 1984;311:108-15.

26 Powell R, Boast N. The Million Dollar Man. Resource implications for chronic Munchausen's syndrome. Br $\mathcal{F}$ Psychiatry 1993;162:253-6. 